\title{
APPLICATION OF MINERAL WATER FROM GEOTHERMAL SOURCE FOR FERMENTATION OF BEETROOT
}

\author{
Short communication \\ Anna WRZODAK*, Justyna SZWEJDA-GRZYBOWSKA \\ Research Institute of Horticulture, Department of Storage and Processing of Fruit and Vegetables \\ Konstytucji 3 Maja 1/3, 96-100 Skierniewice, Poland \\ Received: March 2020; Accepted: May 2020
}

\begin{abstract}
The aim of the study was evaluation of water from geothermal source Uniejów for spontaneous fermentation of red beetroot, assuming that beetroot values in combination with highly mineralized water will lead to innovative products with excellent organoleptic properties and potentially higher pro-health activity in comparison to the products available in the market. In the result, the use of geothermal water allowed to obtain fermented beet cubes and juice characterized by high sensory quality, unique mineral aftertaste, very good flesh firmness and viscosity. A significant impact on the physicochemical characteristics and sensory quality had the original quality of cultivar, which was evaluated higher for 'Wodan $F_{1}$ ' than for 'Alto $F_{1}$ '. There were no significant differences in the contents of the selected compounds depending on the type of water, except for cubic texture, which was higher evaluated after fermentation in geothermal water.
\end{abstract}

Key words: fermented beetroot, geothermal water, physicochemical analysis, sensory quality

\section{INTRODUCTION}

Fermentation is one of the oldest technologies, which prolongs the shelf life of food products and increases their nutritional and organoleptic values (Kavitake et al. 2018). Nowadays, fermentation still plays a significant role in the preservation and maintenance of food safety. Properly fermented food containing lactobacilli and bifidobacteria remains the best proof of their safety and the storability (Bourdichon et al. 2012). Fermentation may be the most economical and straightforward way of improving nutritional value, sensory properties and functional qualities of food. Particularly, fermented vegetables are low-caloric food as they contain considerably lower quantities of sugars compared to raw vegetables. Lactic acid may also lower the gut $\mathrm{pH}$, therefore inhibiting the development of putrefactive bacteria. In addition, fermented vegetables can be a source of lactic bacteria strains with probiotic features (Manning et al. 2004).
In recent years, roots of Beta vulgaris L. has attracted considerable attention as a functional health promoting food (Chhikara et al. 2019). It is a rich source of biologically active substances, such as carotenoids (Dias et al. 2009), glycine betaine (de Zwart et al. 2003), saponins (Atamanova et al. 2005), betacyanins, folates (Jastrebova et al. 2003), betanin, polyphenols and flavonoids (Váli et al. 2007), nitrates, ascorbic acid (Clifford et al. 2015) and minerals, such as potassium, sodium, phosphorus, magnesium etc. (Ormsbee et al. 2013). Betalains are classified as cationic antioxidants, possessing hydroxyl group $(-\mathrm{OH})$ at the $\mathrm{C}_{6}$ position and amino group (-NH) in the ring; therefore, they are good electron donors (Strack et al. 2003), and may act as scavengers of free radicals (Pedreño \& Escribano 2000). Studies of Klewicka and Czyżowska (2011) were focused on the effect of low temperature storage and fermentation of beet juice on betalain profiles, and their biological stability. 
Beetroot belongs to vegetables eaten in relatively large quantities throughout the year; it is cheap and easily available as fresh material on the Polish market. This raw material is mainly consumed after its processing, during which the structure of betalain dyes is destroyed and antioxidant properties of this raw material are reduced (Sawicki \& Wiczkowski 2018).

Generally, in Poland, well, spring or tap water is used to fermentation of vegetables. Water hardness is of great importance in acidification. Due to the higher content of calcium salts, hard water has a positive effect on maintaining the favorable consistency of fermented products. Water used for making brine should contain not less than $0.1 \mathrm{~g}$ of $\mathrm{CaO}$ per liter of water. Sometimes, to reduce the risk of softening of cucumbers, $7.5 \mathrm{~g} \cdot \mathrm{dm}^{-3}$ calcium chloride or other calcium salt is added to the brine. The brine should contain up to $5-7 \% \mathrm{NaCl}$ and must be clear and free of impurities (Elkner \& Smolińska 2002). One of the studies have documented using of different types of salts containing of $\mathrm{Ca}^{2+}$ and $\mathrm{Mg}^{2+}$ in brine and the influence of these on the texture of fermented cucumbers (Yoo et al. 2006).

Geothermal water is used in heating households and providing hot water, as well as in balnealtherapeutic and recreational services, but also for the production of drinks. Poland, mainly the Polish lowlands, the Sudety and the Carpathian Mountains, possess huge potential and resources of geothermal energy. Underground water is mostly found at a depth of $3000-4000 \mathrm{~m}$ and temperature can be from 20 to $130{ }^{\circ} \mathrm{C}$. The level of mineralization of geothermal water is diverse and ranges from 1 to $100 \mathrm{~g} \cdot \mathrm{dm}^{-3}$. According to Latour and Drobnik (2016), the analysis of chemical composition of water from 60 geothermal sources in different regions of Poland showed their possible usefulness for various purposes. It is assumed that the use of mineral water from geothermal sources in vegetable processing will result in a product with improved nutritional value, health and sensory quality. We propose the use of geothermal water from Uniejów that is a highly mineralized composition of chloride-sodium-calcium-magnesium, in the process of fermentation of vegetables, instead of tap water conventionally used for this purpose (Table 1).
Table 1. Chemical composition (in $\mathrm{mg} \cdot \mathrm{dm}^{-3}$ ) of geothermal water from the PIG/AGH-2 well in Uniejów (based on the PZH certificate from 2018) and tap water in Skierniewice (Laboratory for Quality Testing of Horticultural Products, Research Institute of Horticulture)

\begin{tabular}{lcc}
\hline Elements & $\begin{array}{c}\text { Geothermal water } \\
\text { (Uniejów) }\end{array}$ & $\begin{array}{c}\text { Tap water } \\
\text { (Skierniewice) }\end{array}$ \\
\hline $\mathrm{K}^{+}$ & 19.0 & 3.24 \\
$\mathrm{P}^{+}$ & 0.01 & 0.02 \\
$\mathrm{Mg}^{2+}$ & 34.03 & 14.5 \\
$\mathrm{Ca}^{2+}$ & 140.28 & 77.6 \\
$\mathrm{Na}^{+}$ & 2290.0 & 8.66 \\
$\mathrm{SO}_{4}{ }^{2-}$ & 127.56 & 24.6 \\
$\mathrm{~B}^{+}$ & 0.75 & 0.11 \\
$\mathrm{Cu}^{2+}$ & 0.04 & 0.01 \\
$\mathrm{Fe}^{2+/ 3+}$ & 1.0 & 0.01 \\
$\mathrm{Mn}^{2+}$ & 0.002 & 0.03 \\
$\mathrm{Zn}^{2+}$ & 0.0175 & 0.17 \\
$\mathrm{Cl}^{-}$ & 3615.9 & 15.4 \\
$\mathrm{Hg}^{2+}, \mathrm{As}^{3+15+}, \mathrm{Cd}^{2+}, \mathrm{Pb}^{2+}$ & $<0.001$ & $<0.001$ \\
\hline
\end{tabular}

There is no literature dealing with vegetable fermentation technology based on the use of geothermal water for brine. Therefore, the purpose of our research was to evaluate geothermal water from Uniejów for making brine used in the process of fermentation of beetroot with the aim to obtain product with increased nutritional and pro-health value.

\section{MATERIAL AND METHODS}

\section{Fermentation process}

Red beets cultivars 'Alto $\mathrm{F}_{1}$ ' and 'Wodan $\mathrm{F}_{1}$ ' (Bejo Zaden) were used in the experiments. The beets were washed, peeled, cut into cubes $(1 \mathrm{~cm} \times 1 \mathrm{~cm})$ and then put into $1300 \mathrm{ml}$ sterile glass jars with standard spices used in fermentation (garlic, horse radish, dill). The jars were filled with tap water (as a control) taken from Skierniewice waterworks or with geothermal water taken from Uniejów source. The table salt was added to the final concentration of $\mathrm{NaCl}$ in brine $3.5 \%$. 
The lactic fermentation process was carried out in agreement with the current standard procedures. According to Elkner (2004), in the initial phase of fermentation, a temperature of about $20{ }^{\circ} \mathrm{C}$ is recommended, during which there is development of bacteria of the genus Aerogenes and bacteria peptizing (protein breakdown), and then lactic acid bacteria quickly acidifying the environment. Gradual lowering of temperature slows down the rapid fermentation process - for this stage, the recommended temperature is $10-12{ }^{\circ} \mathrm{C}$. At this temperature, carbon dioxide dissolves more easily in the brine. The fermentation process, to be correct, can proceed slowly, and after 30-40 days, the lactic acid content in products should reach $0.7 \%$. To fulfill these requirements, in our experiment fermentation was conducted for 2-3 days at a temperature of $20^{\circ} \mathrm{C}$, then for the next 10 days at $12-15^{\circ} \mathrm{C}$, finally at $5{ }^{\circ} \mathrm{C}$. After a month, chemical and sensory analyses were carried out. The quality of the obtained fresh and fermented red beets (cubes and juice) was evaluated on the basis of sensory assessment of each descriptors, as well as content of betanin dyes, $\mathrm{L}^{*} \mathrm{a}^{*} \mathrm{~b}^{*}$ color parameters, $\mathrm{pH}$, content of sugars and dry matter, and hardness were evaluated.

\section{Analytical methods}

Dry matter was determined by gravimetric method and expressed as \% of fresh mass (FM). Extract was determined by refractometric method and expressed as $\%$ of FM. Total sugars content was determined with the standard Luff-Schoorl's method and expressed as \% of FM.

Total polyphenols were evaluated in $10 \mathrm{~g} \mathrm{sam}-$ ples of roots that were homogenized with $60 \mathrm{ml}$ of $80 \%$ aqueous methanol for 10 min using Ultra Turrax T-25 blender. The homogenate was then filtered through No. 2 Whatman paper on Büchner funnel under vacuum. The residue was re-extracted with $50 \%$ methanol and supernatants were pooled, transferred to $100 \mathrm{ml}$ volumetric flask and filled to the mark with water. The extract was analyzed for total phenolics content with Folin-Ciocalteu reagent, according to the method used by Van der Sluis et al. (2002) with catechin as the standard. Results were expressed in mg per kg of FM.
Acidity value of the fruit pulp was determined with the potentiometric method, using the potentiometer equipped with two electrodes.

The content of betalain dyes was determined by spectrophotometric differential method of Nilsson (1970). The content of violet dyes was determined simultaneously as purple beta cyanides and yellow betaxanthin contents. Before the absorbance measurement, the sample was diluted with $\mathrm{pH} 6.5$ phosphate buffer, in such a proportion that the absorbance value was in the range of $0.2-0.8$. A phosphate buffer was used as a zero sample. Absorbance was measured at three wavelengths: 476, 538 and $600 \mathrm{~nm}$. The data was expressed as \% of FM.

Firmness was determined using the Instron 1140 texturometer and fruit color (Hunter Lab) using the Hunter CQ Spec.

Statistical analysis performed with STATISTICA v.10 (StatSoft 2011) as one-way analysis of variance for cultivars or types of water, separately for each cultivar. The significant differences between means were determined at $\mathrm{p}=0.05$ by Tukey's HSD test. The data were collected in triplicates $(n=3)$.

\section{The sensory evaluation}

Sensory evaluation of fermented beetroot was performed in a laboratory by 10 experts' panel, using the quantitative description analysis (QDA), according to the ISO standards (Anonymous 1998). Sensory quality of fermented products (cubes and juice) was evaluated for odor, texture and taste. In the first part of QDA procedure, the brainstorming sessions were run to select attributes for the beetroot products. Finally, a set of 8 quality attributes and overall sensory quality were evaluated. The assessments for each descriptor were marked on nonstructural lines, with anchoring points (low-high intensity of impression). Results were converted to numerical values $(0-10)$. Each analysis was performed in two independent sessions, so the results in the tables represent the mean of these sessions. The ANALSENS software was used to perform the evaluation on processing the results. Significance of differences between means was estimated using Tukey's HSD test $(p=0.05)$. 


\section{RESULTS AND DISCUSSION}

It was found that the two tested cultivars of beetroot differed from each other in the content of individual components in fresh roots, but the differences were not always statistically significant. The significantly higher content of dry matter was found in roots of 'Wodan $F_{1}$ ' $(16.5 \%)$ as compared with 'Alto $F_{1}$ ' $(15.4 \%)$. In roots of 'Wodan $F_{1}$ ' also, higher content of extract, total sugars, total polyphenols and higher hardness were scored than in the beets of 'Alto $F_{1}$ ' (Table 2). There was no significant difference in the $\mathrm{pH}$ value and color coordinates. The content of betanin was higher in 'Alto $\mathrm{F}_{1}$ '. After the fermentation process, the above characteristics (except for hardness) did not differ between the products fermented in brine made from water of various sources (Table 3 ). Hardness of the cubes was the only trait that was higher when fermented in geothermal water. The literature indicates that the content of dry matter in different cultivars of beetroots can range from 12 to $20 \%$, including: $4-12 \%$ sugars, $1.5 \%$ protein, $0.1 \%$ fat, and $0.8 \%$ fiber (Janiszewska 2014; Biegańska-Marecik et al. 2007). Makowska (1991) found that the level of the extract depends on the root size: the smaller the root, the higher the content of the extract. In his studies, the content of total polyphenols depended on the cultivar and ranged between 659 and $756 \mathrm{mg} \cdot \mathrm{kg}^{-1}$. After the fermentation process, the content of this compounds ranged from 314 to $450 \mathrm{mg} \cdot \mathrm{kg}^{-1} \mathrm{FM}$.

In the studies of Wruss et al. (2015), the content of total polyphenols in beetroot juices ranged between $0.85-1.29 \mathrm{~g} \cdot \mathrm{dm}^{-3}$. In the studies of Kazimierczak et al. (2016), the level of these compounds in beetroot juice after fermentation process ranged between $37.3-123.3 \mathrm{mg} \cdot 100 \mathrm{~g}^{-1}$ and depended on the cultivation method. Czyżowska et al. (2020) found that the total phenolics content in the fermented beetroot of the cultivar 'Wodan $\mathrm{F}_{1}$ ' ranged from $920 \mathrm{mg} \cdot \mathrm{kg}^{-1}$ after 7 months of cold storage and decreased to $570 \mathrm{mg} \cdot \mathrm{kg}^{-1}$ after 10 months of storage.
In our research, the level of betanin depended on the cultivar and was respectively: in 'Wodan $\mathrm{F}_{1}$ ' beetroots $-0.11 \%$, and in 'Alto $F_{1}$ ' $-0.17 \%$. After the fermentation process, the content of betanin for both cultivars ranged from 0.042 to $0.048 \%$. The type of used water had no significant impact on the level of betanin. The literature showed that the content of betanin in the beetroots depends on the cultivar and ranged between $0.1 \%$ to $0.25 \%$. In the studies of Gościnna and Czapski (2013), the content of betanin in beetroot juice ranged from 1093 to 1890 $\mathrm{mg} \cdot \mathrm{dm}^{-3}$. According to other authors, the content of this compound in beetroots was between 750 and $1300 \mathrm{mg} \cdot \mathrm{kg}^{-1}$ (de Zwart et al. 2003, Petterson et al. 2008; Sawicki \& Wiczkowski 2018). The big differences in the content of betalain dyes may depend on several factors: cultivar, size and shape of root, climatic and agro-technical conditions (Gościnna et al. 2012; Gościnna \& Czapski 2017).

In our experiment, beetroots hardness depended on the cultivar and was higher in 'Wodan $F_{1}$ ' $(89.3 \mathrm{~N})$ than in 'Alto $\mathrm{F}_{1}$ ' $(70.2 \mathrm{~N})$. Moreover, there was a significant difference in the hardness of beet cubes of both cultivars fermented with the use of geothermal water (Tables $2 \& 3$ ).

The sensory assessment of the fermented cubes showed significant differences between cultivars 'Wodan $F_{1}$ ' and 'Alto $F_{1}$ ' in the four descriptors of sensory quality - in beetroot smell and sweet smell and also in the taste, which made higher score of overall quality of 'Wodan $\mathrm{F}_{1}$ ' (Table 4).

In juice, differences were only found in the overall quality and fermented beetroot smell, which were scored higher in 'Wodan $F_{1}$ ' (Table 5). The type of water had a significant effect on the perception of sour taste of juice of 'Wodan $\mathrm{F}_{1}$ ' (Table 4). The differences in the other quality attributes resulting from water type were not significant (Tables 4, 5), except for the higher intensity of sweet smell in juice of cultivar 'Wodan $F_{1}$ ' obtained with the use of geothermal water (Table 5). 
Table 2. The physicochemical traits of two cultivars of beetroots 'Alto $\mathrm{F}_{1}$ ' and 'Wodan $\mathrm{F}_{1}$ ' before fermentation

\begin{tabular}{|c|c|c|c|c|c|c|c|c|c|c|}
\hline \multirow[t]{2}{*}{ Cultivar } & \multirow{2}{*}{$\begin{array}{c}\text { Dry matter } \\
(\%)\end{array}$} & \multirow{2}{*}{$\begin{array}{c}\text { Extract } \\
(\%)\end{array}$} & \multirow[t]{2}{*}{$\mathrm{H}$} & \multirow{2}{*}{$\begin{array}{c}\text { Total sugars } \\
(\%)\end{array}$} & \multirow{2}{*}{$\begin{array}{c}\text { Betanin } \\
(\%)\end{array}$} & \multirow{2}{*}{$\begin{array}{c}\text { Total } \\
\text { polyphenols } \\
\left(\mathrm{mg} \cdot \mathrm{kg}^{-1} \mathrm{FM}\right)\end{array}$} & \multirow{2}{*}{$\begin{array}{l}\text { Hardness } \\
(\mathrm{N})\end{array}$} & \multicolumn{3}{|c|}{$\begin{array}{l}\text { The color coordinates } \\
\text { (according to Hunter) }\end{array}$} \\
\hline & & & & & & & & $\mathrm{L}$ & a & $\mathrm{b}$ \\
\hline "Woda & $3 a$ & $16.8 \pm$ & $6.6 \pm 0$ & $10.05=$ & $8 \mathrm{~b}$ & $756 \pm$ & 89.3 & $12.8 \pm 0.02 \mathrm{a}$ & $6.84 \pm 0.06 \mathrm{a}$ & $1.27 \pm 0.04 \mathrm{a}$ \\
\hline 'Alto $\mathrm{F}_{1}$ ' & $15.43 \pm$ & $13.8 \pm 0.12 \mathrm{~b}$ & $6.4 \pm 0.08 \mathrm{a}$ & $8.7 \pm 0.52 \mathrm{l}$ & $0.17 \pm 0.07 \mathrm{a}$ & $659 \pm 1.98 \mathrm{~b}$ & $70.2 \pm 6.35$ & $2.1 \pm 0.09 \mathrm{a}$ & $6.41 \pm 0.08 \mathrm{a}$ & $1.29 \pm 0 . \mathrm{C}$ \\
\hline
\end{tabular}

Means in the each column marked with the same letter are not different according to Tukey's HSD test $(\mathrm{p}=0.05)$

Table 3. The physicochemical composition of two cultivars of beetroots 'Alto $\mathrm{F}_{1}$ ' and 'Wodan $\mathrm{F}_{1}$ ' after fermentation process in the thermal water from Uniejów and tap water from Skierniewice

\begin{tabular}{|c|c|c|c|c|c|c|c|c|c|}
\hline \multirow{2}{*}{$\begin{array}{c}\text { Type } \\
\text { of water }\end{array}$} & \multirow{2}{*}{$\begin{array}{c}\text { Dry matter } \\
(\%)\end{array}$} & \multirow{2}{*}{$\mathrm{pH}$} & \multirow{2}{*}{$\begin{array}{c}\text { Extract } \\
(\%)\end{array}$} & \multirow{2}{*}{$\begin{array}{c}\text { Total } \\
\text { sugars } \\
(\%) \\
\end{array}$} & \multirow{2}{*}{$\begin{array}{c}\text { Betanin } \\
(\%)\end{array}$} & \multirow{2}{*}{$\begin{array}{c}\text { Total } \\
\text { polyphenols } \\
\left(\mathrm{mg} \cdot \mathrm{kg}^{-1} \mathrm{FM}\right)\end{array}$} & \multirow{2}{*}{$\begin{array}{l}\text { Hardness } \\
(\mathrm{N})\end{array}$} & \multicolumn{2}{|c|}{ The color (according to Hunter) } \\
\hline & & & & & & & & $\mathrm{L}$ & $\mathrm{b}$ \\
\hline \multicolumn{10}{|c|}{ 'Wodan $F_{1}$ ' } \\
\hline geothermal & $10.56 \pm 0.34 \mathrm{a}$ & $4.1 \pm 0.07 \mathrm{a}$ & $8.2 \pm 0.18 \mathrm{a}$ & $2.35 \pm 0.47 \mathrm{a}$ & $0.043 \pm 0.06 \mathrm{a}$ & $450 \pm 1.54 \mathrm{a}$ & $28.1 \pm 9.01 \mathrm{a}$ & $12.21 \pm 0.07 \mathrm{a}$ & $7.34 \pm 0.06 \mathrm{a} \quad 0.07 \pm 0.05 \mathrm{a}$ \\
\hline tap & $10.25 \pm 0.44 \mathrm{a}$ & $4.1 \pm 0.06 \mathrm{a}$ & $8.1 \pm 0.15 \mathrm{a}$ & $2.20 \pm 0.63 \mathrm{a}$ & $0.042 \pm 0.04 \mathrm{a}$ & $444 \pm 1.89 \mathrm{a}$ & $26.6 \pm 7.88 \mathrm{~b}$ & $12.60 \pm 0.11 \mathrm{a}$ & $7.82 \pm 0.14 \mathrm{a} \quad 0.34 \pm 0.02 \mathrm{a}$ \\
\hline \multicolumn{10}{|c|}{ 'Alto $F_{1}$ ' } \\
\hline geothermal & $10.0 \pm 0.56 \mathrm{a}$ & $3.9 \pm 0.08 \mathrm{a}$ & $7.7 \pm 0.12 \mathrm{a}$ & $1.75 \pm 0.58 \mathrm{a}$ & $0.048 \pm 0.09 \mathrm{a}$ & $325 \pm 2.35 \mathrm{a}$ & $24.6 \pm 4.08 \mathrm{a}$ & $12.32 \pm 0.08 \mathrm{a}$ & $6.35 \pm 0.04 \mathrm{a} \quad 0.12 \pm 0.02 \mathrm{a}$ \\
\hline tap & $10.01 \pm 0.32 \mathrm{a}$ & $4.0 \pm 0.06 \mathrm{a}$ & $7.7 \pm 0.17 \mathrm{a}$ & $1.60 \pm 0.43 \mathrm{a}$ & $0.046 \pm 0.07 \mathrm{a}$ & $314 \pm 1.94 \mathrm{a}$ & $22.8 \pm 4.66 \mathrm{~b}$ & $11.91 \pm 0.06 \mathrm{a}$ & $7.17 \pm 0.07 \mathrm{a} \quad 0.10 \pm 0.04 \mathrm{a}$ \\
\hline
\end{tabular}

Table 4. Sensory evaluation of fermented cubes of beetroot based on quality descriptors (scale 0-10)

\begin{tabular}{|c|c|c|c|c|c|c|c|c|c|c|c|c|}
\hline \multirow[b]{3}{*}{$\begin{array}{l}\text { Cultivar; } \\
\text { water } \\
\text { source }\end{array}$} & \multicolumn{12}{|c|}{ Quality descriptors } \\
\hline & $\begin{array}{c}\text { fermented } \\
\text { beetroot } \\
\text { smell }\end{array}$ & $\begin{array}{c}\text { sour } \\
\text { smell }\end{array}$ & $\begin{array}{l}\text { sweet } \\
\text { smell }\end{array}$ & $\begin{array}{l}\text { foreign } \\
\text { smell }\end{array}$ & $\begin{array}{c}\text { color } \\
\text { attractiveness }\end{array}$ & hardness & $\begin{array}{c}\text { fermented } \\
\text { beetroot } \\
\text { taste }\end{array}$ & $\begin{array}{l}\text { sour } \\
\text { taste }\end{array}$ & $\begin{array}{l}\text { salty } \\
\text { taste }\end{array}$ & $\begin{array}{l}\text { bitter } \\
\text { taste }\end{array}$ & $\begin{array}{l}\text { foreign } \\
\text { taste }\end{array}$ & $\begin{array}{c}\text { overall } \\
\text { quality } \\
\text { score }\end{array}$ \\
\hline & 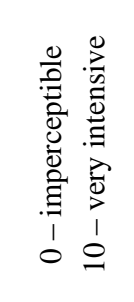 & 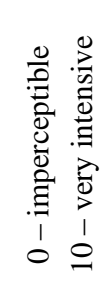 & 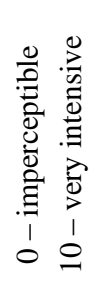 & 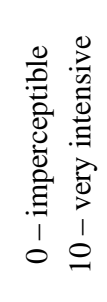 & 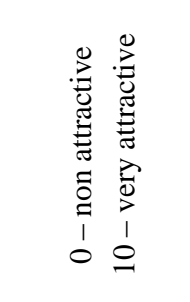 & 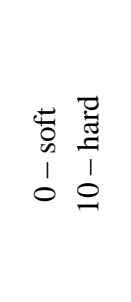 & 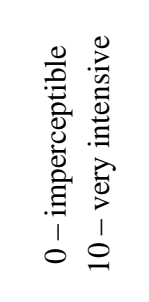 & 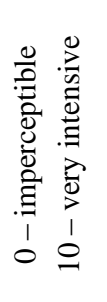 & 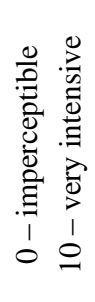 & 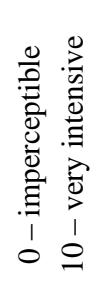 & 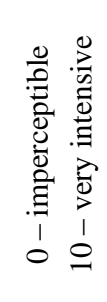 & 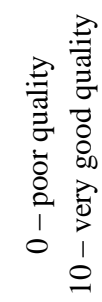 \\
\hline $\begin{array}{l}\text { 'Wodan F1'; } \\
\text { tap }\end{array}$ & $8.3 \mathrm{a}$ & $3.5 \mathrm{a}$ & $0.7 \mathrm{a}$ & $0 \mathrm{a}$ & $7.9 \mathrm{a}$ & $8.0 \mathrm{a}$ & $8.2 \mathrm{a}$ & $5.0 \mathrm{a}$ & $1.3 \mathrm{a}$ & $0 \mathrm{a}$ & $0 \mathrm{a}$ & $8.4 \mathrm{a}$ \\
\hline $\begin{array}{l}\text { 'Wodan F1'; } \\
\text { geothermal }\end{array}$ & $8.1 \mathrm{a}$ & $3.4 \mathrm{a}$ & $0.8 \mathrm{a}$ & $0 \mathrm{a}$ & $7.4 \mathrm{a}$ & $8.7 \mathrm{a}$ & $7.7 \mathrm{a}$ & $4.8 \mathrm{a}$ & $1.5 \mathrm{a}$ & $0 \mathrm{a}$ & $0 \mathrm{a}$ & $8.8 \mathrm{a}$ \\
\hline 'Wodan F1' & $8.2 \mathrm{~A}$ & 3.5A & $0.8 \mathrm{~A}$ & $\mathbf{0 A}$ & 7.6A & $8.3 \mathrm{~A}$ & 8.0A & 4.9A & $1.4 \mathrm{~A}$ & $\mathbf{0 A}$ & $\mathbf{0 A}$ & 8.6A \\
\hline $\begin{array}{l}\text { 'Alto } F_{1} \text { '; } \\
\text { tap }\end{array}$ & $7.0 \mathrm{a}$ & $3.0 \mathrm{a}$ & $0.7 \mathrm{a}$ & $0 \mathrm{a}$ & $7.4 \mathrm{a}$ & $8.3 \mathrm{a}$ & $6.6 a b$ & $4.1 \mathrm{ab}$ & $1.4 \mathrm{a}$ & $0 \mathrm{a}$ & $0 \mathrm{a}$ & $7.5 \mathrm{a}$ \\
\hline $\begin{array}{l}\text { 'Alto } F_{1} \text { '; } \\
\text { geothermal }\end{array}$ & $7.3 \mathrm{a}$ & $2.7 \mathrm{a}$ & $0.5 \mathrm{a}$ & $0 \mathrm{a}$ & $7.9 \mathrm{a}$ & $8.5 \mathrm{a}$ & $7.3 \mathrm{a}$ & $5.3 \mathrm{a}$ & $1.8 \mathrm{a}$ & $0 \mathrm{a}$ & $0 \mathrm{a}$ & $7.6 \mathrm{a}$ \\
\hline 'Alto F' & 7.1B & 2.9AB & 0.6A & $\mathbf{0 A}$ & 7.6A & 8.4A & 7.0B & 4.7A & $1.6 \mathrm{~A}$ & $\mathbf{0 A}$ & $\mathbf{0 A}$ & 7.5B \\
\hline
\end{tabular}

Means in the column for each cultivar and between cultivars marked with the same letter are not different according to Tukey's HSD test $(\mathrm{p}=0.05)$ 
Table 5. Sensory evaluation of fermented juice of beetroot based on quality descriptors (scale 0-10)

\begin{tabular}{|c|c|c|c|c|c|c|c|c|c|c|c|c|c|}
\hline \multirow[b]{3}{*}{$\begin{array}{l}\text { Cultivar; } \\
\text { water } \\
\text { source }\end{array}$} & \multicolumn{13}{|c|}{ Quality descriptors } \\
\hline & $\begin{array}{c}\text { fermented } \\
\text { beetroot } \\
\text { smell }\end{array}$ & $\begin{array}{l}\text { sweet } \\
\text { smell }\end{array}$ & $\begin{array}{l}\text { foreign } \\
\text { smell }\end{array}$ & color & $\begin{array}{c}\text { color } \\
\text { attractiveness }\end{array}$ & viscosity & $\begin{array}{c}\text { fermented } \\
\text { beetroot } \\
\text { taste }\end{array}$ & $\begin{array}{l}\text { sweet } \\
\text { taste }\end{array}$ & $\begin{array}{l}\text { sour } \\
\text { taste }\end{array}$ & $\begin{array}{l}\text { bitter } \\
\text { taste }\end{array}$ & $\begin{array}{c}\text { harmo- } \\
\text { nizing } \\
\text { taste }\end{array}$ & $\begin{array}{l}\text { foreign } \\
\text { taste }\end{array}$ & $\begin{array}{c}\text { overall } \\
\text { quality } \\
\text { score }\end{array}$ \\
\hline & 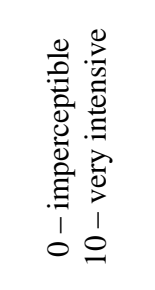 & 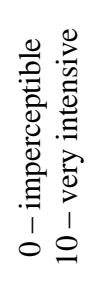 & 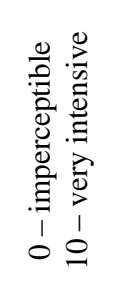 & 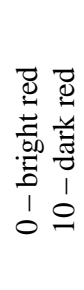 & 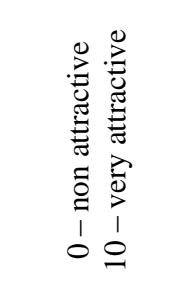 & 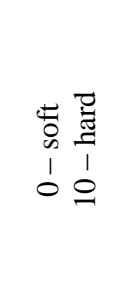 & 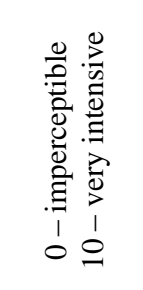 & 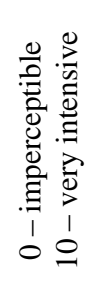 & 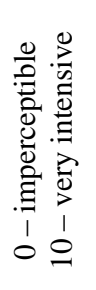 & 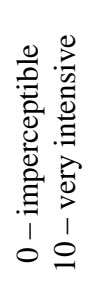 & $\begin{array}{ll}\Xi & \overline{0} \\
0 & 0 \\
0 & 0 \\
0 & 0 \\
0 & 0 \\
1 & 1 \\
0 & 0\end{array}$ & 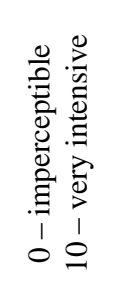 & 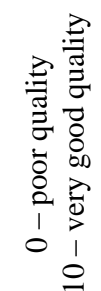 \\
\hline $\begin{array}{l}\text { 'Wodan F1'; } \\
\text { tap }\end{array}$ & $6.2 \mathrm{a}$ & $0.9 \mathrm{~b}$ & $0 \mathrm{a}$ & $8.5 \mathrm{a}$ & $9.0 \mathrm{a}$ & $3.6 a b$ & $8.0 \mathrm{a}$ & $2.0 \mathrm{a}$ & $5.6 \mathrm{a}$ & $0.1 \mathrm{a}$ & $5.1 \mathrm{a}$ & $0 \mathrm{a}$ & $8.1 \mathrm{a}$ \\
\hline $\begin{array}{l}\text { 'Wodan } F_{1} \text { '; } \\
\text { geothermal }\end{array}$ & $6.2 \mathrm{a}$ & $1.9 \mathrm{a}$ & $0 \mathrm{a}$ & $9.0 \mathrm{a}$ & $9.4 \mathrm{a}$ & $4.8 \mathrm{a}$ & $8.1 \mathrm{a}$ & $2.5 \mathrm{a}$ & $4.7 \mathrm{ab}$ & $0.3 \mathrm{a}$ & $4.4 \mathrm{ab}$ & $0 \mathrm{a}$ & $8.1 \mathrm{a}$ \\
\hline 'Wodan $F_{1}$ ' & $6.2 \mathrm{~A}$ & $1.4 \mathrm{~A}$ & $\mathbf{0 A}$ & 8.8A & $9.2 \mathrm{~A}$ & $4.2 \mathrm{~A}$ & $8.1 \mathrm{~A}$ & $2.2 \mathrm{~A}$ & $5.2 \mathrm{~A}$ & $0.2 \mathrm{~A}$ & $4.8 \mathrm{~A}$ & $\mathbf{0 A}$ & 8.1A \\
\hline $\begin{array}{l}\text { 'Alto F1'; } \\
\text { tap }\end{array}$ & $4.7 \mathrm{~b}$ & $1.0 \mathrm{a}$ & $0 \mathrm{a}$ & $8.9 \mathrm{a}$ & $9.2 \mathrm{a}$ & $4.6 a b$ & $8.4 \mathrm{a}$ & $2.3 \mathrm{a}$ & $4.8 \mathrm{ab}$ & $0.1 \mathrm{a}$ & $4.7 \mathrm{a}$ & 0a & $7.5 \mathrm{a}$ \\
\hline $\begin{array}{l}\text { 'Alto F1'; } \\
\text { geothermal }\end{array}$ & $5.7 \mathrm{a}$ & $1.3 \mathrm{a}$ & $0 \mathrm{a}$ & $8.7 \mathrm{a}$ & $9.2 \mathrm{a}$ & $5.1 \mathrm{a}$ & $8.0 \mathrm{a}$ & $2.9 \mathrm{a}$ & $5.1 \mathrm{a}$ & $0.1 \mathrm{a}$ & $4.9 \mathrm{a}$ & $0 \mathrm{a}$ & $7.7 \mathrm{a}$ \\
\hline 'Alto $F_{1}$ ' & $5.2 \mathrm{~B}$ & $1.2 \mathrm{~A}$ & $\mathbf{0 A}$ & 8.8A & $9.2 \mathrm{~A}$ & 4.9A & $8.2 \mathrm{~A}$ & $2.6 \mathrm{~A}$ & $5.0 \mathrm{~A}$ & $\mathbf{0 . 1 A}$ & 4.8A & $\mathbf{0 A}$ & 7.6AB \\
\hline
\end{tabular}

Means in the column for each cultivar and between cultivars marked with the same letter are not different according to Tukey's HSD test $(\mathrm{p}=0.05)$

\section{CONCLUSION}

Results of the study showed some significant differences in physicochemical composition and sensory quality of the fermented beetroots products (cubes and juice), which depended mostly on the cultivar and only little on the water type used for making brine. A significantly higher content of analyzed compounds was found in the cultivar 'Wodan $F_{1}$ ' than in 'Alto $F_{1}$ '. Used water had influence only on the hardness, which was higher in cubes fermented in Uniejów water. The fermented beetroot cubes 'Wodan $F_{1}$ ' from the geothermal water was characterized by the best scores of overall quality due to the highest intensity of fermented beetroot taste and smell.

\section{REFERENCES}

Atamanova S.A., Brezhneva T.A., Slivkin A.I., Nikolaevskii V.A., Selemenev V.F., Mironenko N.V. 2005. Isolation of saponins from table beetroot and primary evaluation of their pharmacological activity. Pharmaceutical Chemistry Journal 39(12): 650-652. DOI: 10.1007/s11094-006-0038-2.
Biegańska-Marecik R., Czapski J., Błaszczyk P. 2007. Determination of cultivar and technological process effect on the occurrence of bitter taste in red beet. Żywność. Nauka. Technologia. Jakość. 3(52): 62-70. [in Polish with English abstract]

Bourdichon F., Casaregola S., Farrokh C., Frisvad J.C., Gerds M.L., Hammes W.P. et al. 2012. Food fermentations: microorganisms with technological beneficial use. International Journal of Food Microbiology 154: 87-97. DOI: 10.1016/j.ijfoodmicro.2011.12.030.

Chhikara N., Kushwaha K., Sharma P., Gat Y., Panghal A. 2019. Bioactive compounds of beetroot and utilization in food processing industry: a critical review. Food Chemistry 272: 192-200. DOI: 10.1016/j.foodchem.2018.08.022.

Clifford T., Howatson G., West D.J., Stevenson E.J. 2015. The potential benefits of red beetroot supplementation in health and disease. Nutrients 7(4): 2801-2822. DOI: 10.3390/nu7042801.

Czyżowska A., Siemianowska K., Śniadowska M., Nowak A. 2020. Bioactive compounds and microbial quality of stored fermented red beetroots and red beetroot juice. Polish Journal of Food and $\mathrm{Nu}-$ trition Sciences 70: 35-44. DOI: 10.31883/pjfns/116611. 
Dias M.G., Camões M.F.G.F.C., Oliveira L. 2009. Carotenoids in traditional Portuguese fruits and vegetables. Food Chemistry 113: 808-815. DOI: 10.1016/j.foodchem.2008.08.002.

Elkner K., Smolińska U. 2002. The effect of starter bacterial culture on the quality factors of sauerkraut. Vegetable Crops Research Bulletin 57: 107-118.

Elkner K. 2004. Jakość ogórków kiszonych II. Hasło Ogrodnicze 9: 80-82. [in Polish]

Gościnna K., Czapski J. 2013. Wpływ odmiany na zawartość barwników betalainowych, betainy, azotanów i cechy sensoryczne soków z buraka ćwikłowego. Przemysł Fermentacyjny i OwocowoWarzywny 57(11): 9-11. [in Polish]

Gościnna K., Czapski J. 2017. Effect on the size and parts of beetroot roots on health promoting compounds and antioxidant capacity juice. Zeszyty Problemowe Postępów Nauk Rolniczych 588: 149-157. DOI: 10.22630/zppnr.2017.588.14. [in Polish with English abstract]

Gościnna K., Czapski J., Mikołajczyk-Bator K., Kidoń M. 2012. Content betalain pigments, nitrates and antioxidant capacity of beetroot juices depending on cultivars and the size of beetroot roots. Aparatura Badawcza i Dydaktyczna 17(3): 85-90. [in Polish with English abstract]

Janiszewska E. 2014. Microencapsulated beetroot juice as a potential source of betalain. Powder Technology 264: 190-196. DOI: 10.1016/j.powtec.2014.05.032.

Jastrebova J., Witthöft C., Grahn A., Svensson U., Jägerstad M. 2003. HPLC determination of folates in raw and processed beetroots. Food chemistry 80: 579588. DOI: 10.1016/s0308-8146(02)00506-x.

Kavitake D., Kandasamy S., Devi P.B., Shetty P.H. 2018. Recent developments on encapsulation of lactic acid bacteria as potential starter culture in fermented foods - a review. Food Bioscience 21: 34 44. DOI: 10.1016/j.fbio.2017.11.003.

Kazimierczak R., Siłakiewicz A., Hallmann E., ŚrednickaTober D., Rembiałkowska E. 2016. Chemical composition of selected beetroot juices in relation to beetroot production system and processing technology. Notulae Botanicae Horti Agrobotanici Cluj-Napoca 44(2): 491-498. DOI: 10.15835/nbha44210372.

Klewicka E., Czyżowska A. 2011. Biological stability of lactofermented beetroot juice during refrigerated storage. Polish Journal of Food and Nutrition Sciences 61: 251-256. DOI: 10.2478/v10222-011-0028-2.

Latour T., Drobnik M. 2016. Geothermal waters recognized in Poland - Biochemical properties determin- ing their usefulness for medical treatment or recreation. Technika Poszukiwań Geologicznych 55(1): 67-74. [in Polish]

Makowska D. 1991. Ocena wartości technologicznej nowych odmian buraków ćwikłowych na podstawie zawartości ekstraktu ogólnego. Praca magisterska, Akademia Rolnicza, Poznań. [in Polish]

Manning T.S., Rastall R., Gibson G. 2004. Prebiotics and lactic acid bacteria. In: Salminen S., von Wright A., Ouwehand A. (Eds.), Lactic Acid Bacteria: Microbiological and Functional Aspects, 3rd ed. Marcel Dekker, USA, pp. 407-418. DOI: 10.1201/9780824752033.ch13.

Nilsson T. 1970. Studies into the pigments in beetroot (Beta vulgaris L. ssp. vulgaris var. rubra L.). Annals of the Agricultural College of Sweden 36: 179-219.

Ormsbee M.J., Lox J., Arciero P.J. 2013. Beetroot juice and exercise performance. Nutrition and Dietary Supplements 5: 27-35. DOI: 10.2147/nds.s52664.

Patterson K.Y., Bhagwat S.A., Williams J.R., Howe J.C., Holden J.M. 2008. USDA Database for the Choline Content of Common Foods, Release 2. United States Department of Agriculture, Agricultural Research Service, $37 \mathrm{p}$.

Pedreño M.A., Escribano J. 2000. Studying the oxidant and the antiradical activity of betalain from beetroot. Journal of Biological Education 35: 49-51. DOI: $10.1080 / 00219266.2000 .9655736$.

PN-ISO 8589:1998. Analiza sensoryczna. Ogólne wytyczne projektowania pracowni analizy sensorycznej. Polish Committee for Standardization. [in Polish]

Sawicki T., Wiczkowski W. 2018. The effects of boiling and fermentation on betalain profiles and antioxidant capacities of red beetroot products. Food Chemistry 259: 292-303. DOI: 10.1016/j.foodchem.2018.03.143.

Van der Sluis A.A., Dekker M., Skrede G., Jongen W.M.F. 2002. Activity and concentration of polyphenolic antioxidants in apple juice. 1. Effect of existing production methods. Journal of Agricultural and Food Chemistry 50(25): 7211-7219. DOI: 10.1021/jf020115h.

Strack D., Vogt T., Schliemann W. 2003. Recent advances in betalain research. Phytochemistry 62: 247-269. DOI: 10.1016/s0031-9422(02)00564-2.

Váli L., Stefanovits-Bányai É., Szentmihályi K., Fébel H., Sárdi É., Lugasi A. et al. 2007. Liver-protecting effects of table beet (Beta vulgaris var. rubra) during ischemia-reperfusion. Nutrition 23: 172-178. DOI: 10.1016/j.nut.2006.11.004. 
Wruss J., Waldenberger G., Huemer S., Uygun P., Lanzerstorfer P., Müller U. et al. 2015. Compositional characteristics of commercial beetroot products and beetroot juice prepared from seven beetroot varieties grown in Upper Austria. Journal of Food Composition and Analysis 42: 46-55. DOI: 10.1016/j.jfca.2015.03.005.

Yoo K.M., Hwang I.K., Ji G.E., Moon B.K. 2006. Effects of salts and preheating temperature of brine on the texture of pickled cucumbers. Journal of Food Science 71: 97-101. DOI: 10.1111/j.13652621.2006.tb08889.x.

de Zwart F.J., Slow S., Payne R.J., Lever M., George P.M., Gerrard J.A., Chambers S.T. 2003. Glycine betaine and glycine betaine analogues in common foods. Food Chemistry 83(2): 197-204. DOI: 10.1016/s0308-8146(03)00063-3. 